\title{
Non-Ridership Presumption Toward New Bus Rapid Transit Purwokerto-Purbalingga Execution
}

Fauzan Romadlon*

Industrial Engineering Department, Faculty of Industrial Engineering and Design, Institut Teknologi Telkom Purwokerto, Purwokerto, 53147, Indonesia

\section{A R T I C L E IN F O}

Article history:

Received: 11 June, 2020

Accepted: 17 August, 2020

Online: 28 August, 2020

Keywords:

Non-ridership

Bus Rapid Transit

Presumption

Purwokerto-Purbalingga

\begin{abstract}
A B S T R A C T
Bus Rapid Transit in Purwokerto-Purbalingga is a new mass transportation mode. Recently, the execution of the BRT has been going on for three years. In terms of service standards to ridership, the BRT has been fulfilled the requirement. However, during the execution, it shall be supported by the non-ridership (local communities) who get the impact as public engagement. The non-ridership impact is captured by observing their presumptions. This study uses quantitative method and survey technique to collect the data by spreading questionnaires to the non-ridership in Purwokerto and Purbalingga. The collected data is analyzed by Analysis of Variance (ANOVA) and Structural Equation Modelling Partial Least Square (SEM-PLS). The ANOVA results show that gender, age ratio, and residence (living area) are significant presumption factors. According to SEM$P L S$ model, the R-squared of non-ridership presumption variables toward the BRT execution as excellent public transportation is at $51.8 \%$ (moderate level). It is found that the economic variable affects the excellent public transportation variable is at $41.4 \%$, and the social variable have a correlation with the excellent public transportation variable is at $36.2 \%$, but not with the environment variable (5.6\% only). Following up these findings, it is recommended that public engagement through the non-ridership presumption will lead the BRT provider to purpose some programs to improve the service and increase the occupancy. So that, the proposed program will attract the sense of awareness and public engagement of the non-ridership toward the BRT execution.
\end{abstract}

\section{Introduction}

Developing worldwide Bus Rapid Transit (BRT) system are increased significantly. Especially in Indonesia, BRT has been implemented not only in the capital city but also in many big cities to support urban mobilities. One of the advantages of BRT is to provide public transportation that relies on the ease of use [1], safety, comfort, and convenience service [2]. The level of BRT service is measured based on BRT effectiveness. BRT service satisfaction is achieved by increasing service procedures, service requirements, and service distinction with conventional public transportation [3]. The quality of service is measured by customer experiences through maintaining bus stop average waiting time, evaluating the impact of operation timetable, and considering BRT capacity [4].

${ }^{*}$ Corresponding Author: Fauzan Romadlon, , Institut Teknologi Telkom Purwokerto, Email: fauzan@ittelkom-pwt.ac.id
Bus stop facilities are compulsory in BRT execution. Bus stops have to integrate with people density which is close to job location to come up with accessibility enhancement [5] and give impacts to potential access informal job opportunities [6]. Besides, the building environment around the bus stops has to consider the density of public facilities and green areas [7]. Affordability of BRT stops shall concern spatial structure [8] and spatial heterogeneity to support BRT planning in service management and infrastructure provision [9]. Therefore, the placement of BRT stops must be considered friendly pedestrian, densely of resident, industrial park connection, and public facilities consideration [10].

In advanced development, BRT has been configured as multimodal transportation networks. It is used to promote the reduction of greenhouse gas emissions and made the diversity of land use [11]. Multimodal and intermodal transportation is enhanced to emphasize of social action while providing reliable and smooth access to the city center [12]. The multimodality index in BRT has a positive relation with BRT ridership by shaping their behavior, land use [13], and transit rate [14]. Ridership perspective 


\section{F. Romadlon / Advances in Science, Technology and Engineering Systems Journal Vol. 5, No. 4, $795-804$ (2020)}

and attitude (behavior) on BRT are the leading indicators to enhance BRT service. Differences between males, elder workers, workers with higher education, and income [15] make the different perspectives of the service. The perspectives are generated motivation challenge of using BRT, such as security, reducing commuting time, staff attitude, and price charges [16]. The impact of land use toward BRT affects high values of properties [17], increased urban development accesses, and optimized time reduction [18].

The success bus implementations are affected overall sustainability such as safety has increase BRT benefit, pro-poor, or lower share of daily earnings [19], and decrease road traffic crashes [20]. On the other hand, BRT implementation faces some issue such as limited government financial support, green transportation issue, and high ridership occupancy [21] and no support form vehicle industries [22]. Sometimes, the execution of BRT has a problem with existing mass transportation, so it requires an understanding of existing transportation to be reorganized [23].

Implementing BRT as public transportation shall include public engagement [24]. The public engagement is to achieve transparent decision with good input from stakeholder [25]. After the public transport is realized, the system of public transportation shall be evaluated whether has economic development impact, sustainability impact, and effect to livable communities [26].

Post-planning or operation step needs more understanding of the connection between the services and public engagement [27]. In some case, public engagement especially from marginal stakeholder who has low power and low interest [28] are less involved. The marginal stakeholder can be identified as three groups: community who has no vehicles and they captive as primary beneficiaries of BRT, community who has vehicle but reluctant, and rich community who has strong voice [29].

Marginal stakeholder engagement can be measured from their presumption. In this study, the marginal stakeholder is nonridership that lives around BRT stops and BRT routes. Their presumption will describe public engagement through new public transportation execution. The presumption can be set as a tool to capture the existing condition of public engagement toward BRT execution especially in different perspective. The new public transportation of the study is BRT Purwokerto-Purbalingga in Indonesia. It is chosen because it merely has been executed for three years but less public awareness.

The public engagement will lead to a sense of local ownership for the BRT in Purwokerto and Purbalingga. A sense of local ownership is used to identify economic probability and community benefits especially, in the job sector, age groups of worker effect, investment time [30], and less $\mathrm{CO} 2$ production [31]. In the other hand, community acceptance increases awareness system to the community, maximizes in implementation, and enhances ridership capacity [32].

\section{Methodology}

\subsection{The Covered Respondent}

The covered area of the study is in Purwokerto and Purbalingga. Purwokerto and Purbalingga are placed in Central Java Province, Indonesia. The operation of BRT is conducted from Ministry of Transport in Central Java Province. The route is started from Bulupitu bus station in Purwokerto until Bukateja bus station in Purbalingga. Bulupitu bus station is central bus station in
Purwokerto that is the transit hub for ridership to travel intercity and interprovince. Bukateja is bus station that is set final destination and it will be transit hub that close to planned airport in Purbalingga. The total route of the BRT is $26.4 \mathrm{~km}$ with 56 bus stops [33].

The study is established by quantitative methods. The questionnaire is set to survey non-ridership who live around the BRT route and bus stops. The respondent is people who live or work around the BRT route and the BRT stop. Data collection technique is conducted by doing direct interviews, face to face, and then the result of these interview is submitted to a Google Form. The proportion of the respondent form both cities are set equal.

\subsection{ANOVA Analysis}

Demographics spread is set as proportional to both cities. The surveyed criteria are gender, residence, job, age, and routine. The presumption is measured using a Likert scale where the scale is five points; 1) Strongly disagree, 2) Disagree, 3) Moderate, 4) Agree, and 5) Strongly agree. After data collection, the presumption questionnaire result is tested for the validity and reliability. The validity test of the questionnaire uses Pearson Correlation and the reliability uses Cronbach' Alpha. Then, the multicollinearity, outliers, and normality test are performed to check whether the data is followed statistical rules or not.

The significance correlation of the demographics of nonridership and the presumption data are approached by using ANOVA (Analysis of Variance) with Minitab 19 software (alfa is $5 \%)$. The hypothesis is set below.

H1: The demographics of non-ridership has significance correlation with their presumption.

\subsection{SEM-PLS Model Evaluation}

Structural Equation Modelling Partial Least Square (SEMPLS) is used to find correlations among the presumptions. The presumption is divided into four categories; social, economic, environment, and excellent public transportation. The modelling is done by Smart-PLS 3 software. After finishing the concept, it is executed by designing a measurement model and set up the path diagram. Then, the last process is evaluated the model and tested the hypotheses.

The SEM-PLS model needs two steps to gain the fit model; model evaluation and structural model analysis. The model evaluation is measured by testing the validity and reliability of the model. The validity test needs three criteria; Convergent Validity, Average Variance Extracted (AVE), and Discriminant Validity. The criterion of reliability is Composite Reliability [34].

Convergent validity is measured based on the correlation between the indicator value and the variable value. The weight value is represented as loading factor or cross loading factor value. The loading factor is high if the value is more than 0.7. But for the initial research, the measurement scale with a loading value of 0.5 to 0.6 is considered as sufficient.

Average Variance Extracted (AVE) is the average of percentage extracted variance value from latent variable that is estimated through the loading standardize. The minimum AVE value is $0.5(1)$.

$$
\mathrm{AVE}=\frac{\sum_{i=1}^{n} \lambda_{i}}{n}
$$




\section{F. Romadlon / Advances in Science, Technology and Engineering Systems Journal Vol. 5, No. 4, $795-804$ (2020)}

Where $\lambda$ is standardize loading factor, $i$ means amount of indicator and $n$ is amount of data.

Discriminant Validity can be calculated by comparing the square root of Average Variance Extracted (AVE) values. If the square root of $\mathrm{AVE}$ value is higher than the correlation value between latent variables, then discriminant validity can be considered as fulfilled. Then, the criterion of reliability model is Composite Reliability. The latent variable can achieve the reliability if minimum the Composite Reliability value is 0.6.

\subsection{Structural Model Analysis}

The structural model analysis is set up to know the relationship among constructed model, the significance value, and the model itself. The testing criteria is significance probability using Rsquared $\left(\mathrm{R}^{2}\right)$. R-Squared is a method to measure Goodness of Fit (GoF) and to appraise the influence independent latent variable with dependent latent variable. After finishing the structural model analysis, the bootstrapping process is conducted. The bootstrapping process is functioned to minimize the abnormality of the modelled study.

\subsection{Model Hypothesis}

The social, economic, and environmental criteria are used to set as an exogen variables and excellent public transportation as an endogen variable. Each category is built up from related presumptions that are set with significant alfa $5 \%$. The hypothesis of the model is,

H2: The economic variable has positive or significance correlation with excellent public transportation system.

H3: The social variable has positive or significance correlation with excellent public transportation system.

H4: The environment variable has positive or significance correlation with excellent public transportation system.

\section{Result and Discussion}

\subsection{Demographics of The Non-ridership BRT}

In Purwokerto and Purbalingga, the non-ridership respondent of the survey is 138 . The demographics of them can be seen in Table 1.

Table 1: Demographics of Non-ridership BRT

\begin{tabular}{|l|l|r|}
\hline User variable & Distribution (\%) \\
\hline \multirow{3}{*}{ Gender } & Men & 60.87 \\
\cline { 2 - 3 } & Women & 39.13 \\
\hline \multirow{4}{*}{ Residence } & Purwokerto & 43.48 \\
\cline { 2 - 3 } & Purbalingga & 49.28 \\
\cline { 2 - 3 } & Others & 7.25 \\
\hline \multirow{5}{*}{ Age Ratio } & Student & 26.09 \\
\cline { 2 - 3 } & Teacher & 2.90 \\
\cline { 2 - 3 } & Labor & 7.97 \\
\cline { 2 - 3 } & Housewife & 5.80 \\
\cline { 2 - 3 } & Others & 57.25 \\
\cline { 2 - 3 } & $15-25$ & 30.43 \\
\cline { 2 - 3 } & M-35 & 15.22 \\
\hline \multirow{2}{*}{ Attempt } & Tried & 54.35 \\
\cline { 2 - 3 } & Never & 62.32 \\
\hline
\end{tabular}

www.astesj.com
According to Table 1, non-ridership gender is dominated by men at $60.87 \%$, and non-ridership women at $39.13 \%$. The dominated non-ridership is caused by men to work at informal economic sector around the bus stop. Most of them rely on the crowded street to gain the customer. They work as food street sellers, fruit sellers, parking guards, and pedicab drivers. The percentage is high at $57.25 \%$ for the job sector. It is described in Table 1 as other job. Meanwhile, most non-ridership women work as students $(26.09 \%)$, workers $(7.97 \%)$, housewife $(5.8 \%)$, and teachers $(2.90 \%)$. So, their availability around the BRT stops is lower than non-ridership men. Then, most of their age ratio is more than 35 . The age ratio is productive worker age who become a family mainstay. The rest is the age ratio between 15 and 25 and between 26 and 35 . The age ratio between 15 and 25 is dominated by student and between 26 and 35 is dominated by labor and housewife.

Regarding the residence area, most of them are living in Purbalingga (49.28\%), followed by Purwokerto (43.38\%) and others $(7.25 \%)$. Other places mean the non-ridership is living around both cities such as Banyumas, Banjarnegara, and Cilacap Regency. The percentage of Purbalingga is higher than Purwokerto and other places mean that, most of the non-ridership works or stay around the BRT stop. Furthermore, the BRT route in Purbalingga is longer than Purwokerto, so the covered area of the BRT is wider than Purwokerto. People in Purbalingga is more often using the BRT than Purwokerto and others because of the BRT can connect the industrial park from their living residence. The majority of respondents have tried the BRT $(62.32 \%)$. They tried the BRT for many purposes, such as visiting their family, going to work or school, and just for a fun activity.

Table 2: Non-Ridership Presumptions toward BRT

\begin{tabular}{|l|l|}
\hline Code & \multicolumn{1}{|c|}{ Presumption } \\
\hline Q1 & BRT capacity is suitable to fulfill demands \\
\hline Q2 & BRT is a reliable public transportation \\
\hline Q3 & BRT service is better than other public transportation \\
\hline Q4 & BRT accommodates ridership destination \\
\hline Q5 & BRT routes shall be expanded \\
\hline Q6 & BRT can be alternative public transportation \\
\hline Q7 & $\begin{array}{l}\text { BRT provider is followed transportation procedure } \\
\text { service }\end{array}$ \\
\hline Q8 & BRT is environment friendly transportation. \\
\hline Q9 & BRT is on-time schedule transportation. \\
\hline Q10 & $\begin{array}{l}\text { BRT can increase economic productivity for local } \\
\text { people }\end{array}$ \\
\hline Q11 & BRT can open economic opportunity for local people \\
\hline Q12 & BRT can open additional job opportunity \\
\hline Q13 & BRT can decrease the traffic congestion \\
\hline Q14 & BRT improve local people mobility \\
\hline Q15 & BRT can reduce traffic accident \\
\hline Q16 & BRT can reduce fossil fuel use. \\
\hline Q17 & BRT facilitates to access intermodal transportation \\
\hline Q18 & BRT stops are able to be added and expanded. \\
\hline Q19 & Ticket payment shall be set e-payment \\
\hline
\end{tabular}




\subsection{Non-Ridership Presumption}

The experience of non-ridership lead to their presumption. The presumption depicts society or community knowledge of implementing BRT. The presumption is used to measure nonridership participation and awareness even though they have never tried the BRT service.

According to Table 2, there are several criteria of non-ridership presumptions that categorized into 19 presumptions. The queries are divided into four categories. The queries are set based on the non-ridership observations toward the BRT services around their living area. First presumption is economic. The presumption is focused on punctuality of the BRT schedule (Q9), economic productivity for local (Q10), economic opportunity for local (Q11), and additional job opportunity for local (Q12).

The second presumption is social. The presumption is set to measure that the BRT can decrease traffic jams in the cities (Q13), enhance local mobility or movement (Q14) and reduce traffic accidents (Q15). Then, the environment is set for seeking the knowledge of local about green transportation (Q8) and reducing fossil fuel usability in transportation (Q16). The last is a nonridership presumption about common presumption about excellent public transportation. The limitation of excellent public transportation is giving impact to the non-ridership living and their social activities. Excellent public transportation presumption is built up from fulfilling demands based on BRT capacity (Q1), being reliable public transportation (Q2), being excellent service bus than the existing bus (Q3), accommodating ridership destination (Q4). Moreover, BRT route shall be expanded (Q5), the BRT can be alternative transportation (Q6), the BRT provider following the service procedure (Q7), BRT facilitates to access intermodal transportation (Q17), BRT stops are able to be added and expanded (Q18), and implementing e-payment ticket (Q19).

According to Table 3, the result of validity test of the questionnaire (Q1-Q19) are valid. It is shown that the Pearson Correlation values are higher than Pearson Correlation Table (0.455) except Q19. However, Q19 is still included into measurement because the p-value is 0.01 (less than 0.05 ). The result of reliability test is reliable. It is shown from the table that the Cronbach' Alpha is 0.9113 where the value is higher than 0.7 as standard minimum of reliability.

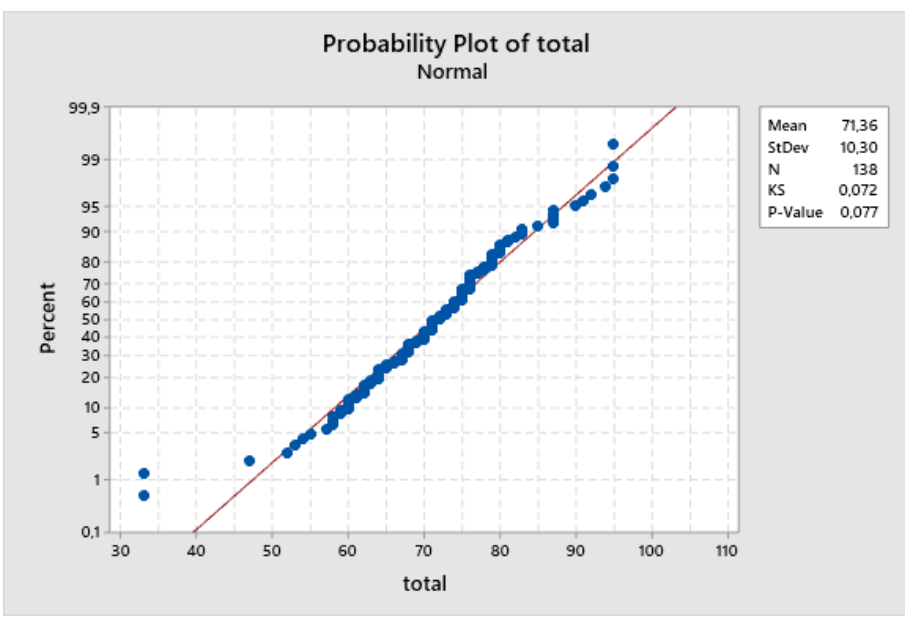

Figure 1: Normality Test Result
Table 3: Validity and Reliability of The Questionnaire Result

\begin{tabular}{|l|l|l|l|}
\hline Code & Pearson Correlation & P-value & $\begin{array}{c}\text { Cronbach' } \\
\text { Alpha }\end{array}$ \\
\hline Q1 & 0.631 & 0.000 & \multirow{1}{*}{} \\
\hline Q2 & 0.637 & 0.000 \\
\hline Q3 & 0.619 & 0.000 \\
\hline Q4 & 0.627 & 0.000 \\
\hline Q5 & 0.614 & 0.000 \\
\hline Q6 & 0.747 & 0.000 \\
\hline Q7 & 0.682 & 0.000 \\
\hline Q8 & 0.648 & 0.000 \\
\hline Q9 & 0.553 & 0.000 \\
\hline Q10 & 0.678 & 0.000 \\
\hline Q11 & 0.695 & 0.000 \\
\hline Q12 & 0.640 & 0.000 \\
\hline Q13 & 0.650 & 0.000 \\
\hline Q14 & 0.709 & 0.000 \\
\hline Q15 & 0.559 & 0.000 \\
\hline Q16 & 0.564 & 0.000 \\
\hline Q17 & 0.665 & 0.000 \\
\hline Q18 & 0.562 & 0.000 \\
\hline Q19 & 0.286 & 0.001 \\
\hline
\end{tabular}

The multicollinearity and outliers test result can be seen in Table 4. According to the table, all of indicator has Varian Inflation Factor (VIF) value that less than 10. It means that there is multicollinearity among the indicators and it guarantees that there is no multicollinearity problem. The outliers test indicates all of pvalue are more than 0.05 . It means that there is no outlier data. The normality test of the data is shown in Figure 1. Regarding to the figure, the data is followed normal distribution rules because the p-values is 0.077 or greater than 0.05 . So, all collected data is sufficient and qualify referring to the statistical rules.

Table 4: Multicollinearity and Outlier Test Result

\begin{tabular}{|l|l|l|l|}
\hline \multirow{2}{*}{ Code } & Multicollinearity & \multicolumn{2}{|c|}{ Outlier } \\
\cline { 2 - 4 } & VIF & G & P-values \\
\hline Q1 & 2,18 & 2,34 & 1,000 \\
\hline Q2 & 2,41 & 2,72 & 0,812 \\
\hline Q3 & 1,69 & 2,81 & 0,603 \\
\hline Q4 & 1,64 & 4,16 & 0,266 \\
\hline Q5 & 1,72 & 3,54 & 0,355 \\
\hline Q6 & 2,42 & 4,40 & 0,108 \\
\hline Q7 & 2,33 & 4,39 & 0,110 \\
\hline Q8 & 2,13 & 3,44 & 0,061 \\
\hline Q9 & 1,57 & 2,65 & 1,000 \\
\hline Q10 & 2,34 & 2,69 & 0,901 \\
\hline Q11 & 2,68 & 2,56 & 1,000 \\
\hline Q12 & 1,53 & 2,75 & 0,736 \\
\hline Q13 & 1,96 & 2,32 & 1,000 \\
\hline
\end{tabular}


F. Romadlon / Advances in Science, Technology and Engineering Systems Journal Vol. 5, No. 4, 795-804 (2020)

\begin{tabular}{|l|l|l|l|}
\hline Q14 & 1,88 & 3,94 & 0,869 \\
\hline Q15 & 1,83 & 1,83 & 1,000 \\
\hline Q16 & 1,61 & 3,19 & 0,159 \\
\hline Q17 & 1,83 & 2,23 & 1,000 \\
\hline Q18 & 1,75 & 3,00 & 0,321 \\
\hline Q19 & 1,19 & 1,55 & 1,000 \\
\hline
\end{tabular}

\subsection{ANOVA Result}

After getting the presumptions data, ANOVA is used to test the significance between demographic factors and the non-ridership presumptions. The result is shown in Table 5.

Table 5: ANOVA Result

\begin{tabular}{|l|l|l|}
\hline Code & Significance Factor & P-value \\
\hline Q1 & - & - \\
\hline Q2 & - & - \\
\hline Q3 & - & - \\
\hline Q4 & Gender & 0.035 \\
\hline Q5 & - & - \\
\hline Q6 & - & - \\
\hline Q7 & - & - \\
\hline Q8 & - & - \\
\hline Q9 & Residence & 0.035 \\
\hline Q10 & Residence & 0.001 \\
\hline Q11 & Residence & 0.008 \\
\hline Q12 & - & - \\
\hline Q13 & Age Ratio & 0.023 \\
\hline Q14 & Residence & 0.006 \\
\hline Q15 & Residence & 0.018 \\
\hline Q16 & Residence & 0.000 \\
\hline Q17 & - & - \\
\hline Q18 & - & - \\
\hline Q19 & Age Ratio & 0.000 \\
\hline
\end{tabular}

According Table 5, gender is significant factor for accommodation ridership destination (Q4). In this case, gender correlates with public transportation. Different gender has different travel pattern in term of using public transportation especially, for non-ridership women. Sometimes, women use more frequently use public transportation than men, so they think that the BRT can transport them to their destination.

Age ratio is a significant factor for reducing traffic congestion (Q13) and implementing e-payment for the BRT (Q19). At traffic congestion, the member of age ratio has different experience toward the BRT service. Before implementing the BRT, some of them experienced that the road condition is crowded, then they hope that after implementing the BRT, the congestion will be reduced. Furthermore, they also hope for the person who drive a private car or ride a motorcycle will switch to use the BRT as the main modes of transportation. Moreover, at e-payment system, more than 35 years old age ratio has different choice. They prefer to use cash rather than e-payment or using an e-card that is

implemented recently. Regular payment is more interesting because they do not need to install any application in mobile phones or bringing e-card for tapping. The rest is age ratio 15-25 and 26-35 are prefer to use a trended application such as e-money or e-payment because most of them have mobile phones or emoney cards.

In the context of living areas for non-ridership, it has significant factor for many queries. Residence correlates with the punctuality of the BRT schedule (Q9), increasing economic productivity for local (Q10), economic opportunity for local (Q11), improving local mobility (Q14), reducing traffic accident (Q15), and reducing fossil fuel use (Q16).

The different city has different presumption. Related to the punctuality of the BRT schedule, non-ridership who stay at Purbalingga has different presumptions with Purwokerto and the other cities. It means that the schedule is not always precise. According to the BRT service, the bus is mobilized every 15 minutes for regular hours and every 10 minutes for peak hours. The BRT does not have an exact schedule because of some limitations such as the quantity of the bus, road condition, traveling time, and break time. In some cases, the BRT will not pick up the ridership because of full capacity, so the ridership shall wait next BRT. The next presumption is enhancing local economic productivity. Purbalingga and the other cities have different presumptions with Purwokerto. The non-ridership in Purbalingga and the other cities think that BRT will increase their productivity because the places have many factories such as artificial eye flashes, wig, and motorcycle exhaust. Many of them are labor at the industries that access to industrial park. On the other hand, Purwokerto has fewer factories than Purbalingga and the other cities, yet it has more offices and banks. So, most of the people at Purwokerto work as private or public employees rather than labor. Moreover, the nonridership hopes that there will be opened new economic access that connects government office, industrial park, bus terminal, railway station, and shopping center.

Next presumption is improving job opportunity for local people. The BRT is seen as a new job vacation even though there is a limited job opportunity in the BRT. The non-ridership hope by implementing the BRT, it will involve local participation and support. The non-ridership expects there will be additional linkage for local to access to gain a new job. Furthermore, the idea is similar to improving non-ridership mobility. By increasing local mobility, the non-ridership will have any public transportation a choice. They can take advantage of the BRT existence or not. At least, they have choice for public transportation that regular and low fare, but if their destination cannot be facilitated, they will choose other public transportation or private vehicle. In terms of opportunity for mobilizing people, among the cities has different presumptions. The non-ridership in Purbalingga and outside both cities will rely on the BRT for fulfilling their mobility Purwokerto is not too reliant on it.

The next presumption that has significant factor is reducing traffic accidents. The BRT is set for being alternative mass transportation. The logic is if many people use the BRT, the traffic is reduced because the private vehicle is few. The non-ridership in Purbalingga think that the BRT will reduce the traffic accident because many labours rely on the BRT. The BRT is more safety than using private vehicles but, the rest living area said that the BRT are not too rely on because the traffic is still lower than Purbalingga. So, in this case, private car is more suitable for going 799 
to work or back home. The last presumption is the BRT is reduced fossil fuel consumption. This is one of a promotion for being sustainable transportation. The case is similar to reducing traffic accidents. Non-ridership thinks by reducing private vehicle the fossil fuel consumption will be low. Practically, the BRT is still not covered all destinations especially in some public area such as the central traditional market and railway station. So, it needs to develop more routes to reach the uncovered area, so that additional ridership can be facilitated. The non-ridership presumptions in Purbalingga is more agree than non-ridership who are living in the outside both cities and Purwokerto.

\subsection{Convergent Validity}

After setting up the hypothesis, we develop a model for analysing the correlation among environment, social, and economic criteria with excellent public transportation criteria using SEM- PLS. The model is constructed using Smart PLS 3 software (Figure 2).

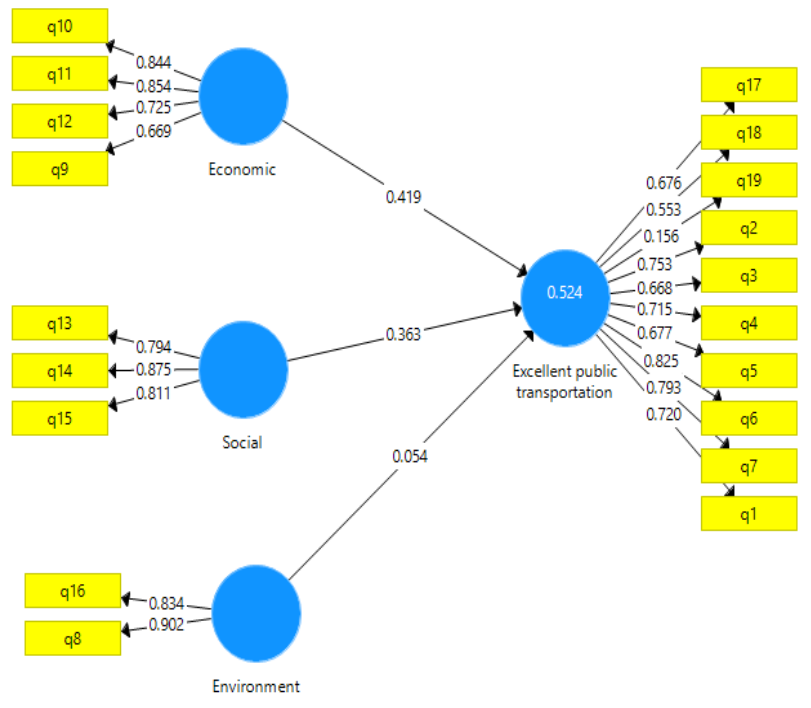

Figure 2: Initial Constructed Model

After the model is constructed, we run the model and get the convergent validity result. Convergent validity is measured based on the correlation among the estimated score component. The value is high if the weight is more than 0.7 . In some case for earlystage research, the measurement scale between 0.5 to 0.6 is reliable enough [34]. The result can be seen in Table 6.

Table 6: Initial Outer Loading (Cross-Loading Factor) Result

\begin{tabular}{|l|r|r|l|l|}
\hline Code & Economic & Environment & $\begin{array}{l}\text { Excellent } \\
\text { Public } \\
\text { Transportation }\end{array}$ & Social \\
\hline Q10 & 0.844 & & & \\
\hline Q11 & 0.854 & & & \\
\hline Q12 & 0.725 & & & \\
\hline Q13 & & & & 0.794 \\
\hline Q14 & & & & 0.875 \\
\hline Q15 & & & & 0.811 \\
\hline Q16 & & 0.834 & & \\
\hline
\end{tabular}

\begin{tabular}{|l|l|l|l|l|}
\hline Q17 & & & 0.676 & \\
\hline Q18 & & & 0.553 & \\
\hline Q19 & & & 0.156 & \\
\hline Q2 & & & 0.753 & \\
\hline Q3 & & & 0.668 & \\
\hline Q4 & & & 0.715 & \\
\hline Q5 & & & 0.677 & \\
\hline Q6 & & & 0.825 & \\
\hline Q7 & & & 0.793 & \\
\hline Q8 & & 0.902 & & \\
\hline Q9 & 0.669 & & & \\
\hline Q1 & & & 0.720 & \\
\hline
\end{tabular}

According to the theory, the limit of the cross-loading factor is 0.5 , and we remove the factor that less than 0.5 . it is found that Q19 has a cross-loading factor less than 0.5 , or the value is 0.159 . So, we eliminate from the constructed model and run the software again. The result is all of the loading factor values are higher than 0.5. It means that fulfilled required convergent validity. Thus, all indicators from the model are appropriate to depict each measured variable (Table 7).

Table 7: Final Outer Loading (Cross Loading Factor) Result

\begin{tabular}{|l|r|r|r|r|}
\hline Code & Economic & Environment & $\begin{array}{l}\text { Excellent } \\
\text { Public } \\
\text { Transportation }\end{array}$ & Social \\
\hline Q10 & 0.844 & & & \\
\hline Q11 & 0.855 & & & \\
\hline Q12 & 0.724 & & & \\
\hline Q13 & & & & 0.792 \\
\hline Q14 & & & & 0.876 \\
\hline Q15 & & & & 0.812 \\
\hline Q16 & & 0.833 & & \\
\hline Q17 & & & 0.676 & \\
\hline Q18 & & & 0.542 & \\
\hline Q2 & & & 0.757 & \\
\hline Q3 & & & 0.668 & \\
\hline Q4 & & & 0.717 & \\
\hline Q5 & & & 0.674 & \\
\hline Q6 & & & 0.827 & \\
\hline Q7 & & & 0.800 & \\
\hline Q8 & & & & \\
\hline Q9 & 0.667 & & & \\
\hline Q1 & & & & \\
\hline
\end{tabular}

\subsection{Average Variance Extracted (AVE)}

The higher AVE value means, the better of correlation among the constructed model. The minimum required values of AVE are 0.5. According to Table 8, all of the variables have AVE values higher than 0.5 . So, it can be mentioned that all of the variables are suitable to fulfil minimum requirement. 


\section{F. Romadlon / Advances in Science, Technology and Engineering Systems Journal Vol. 5, No. 4, 795-804 (2020)}

Table 8: Average Variance Extracted (AVE) Result

\begin{tabular}{|c|c|c|c|c|c|}
\hline Variable & $\begin{array}{c}\text { Cronbach's } \\
\text { Alpha }\end{array}$ & rho A & $\begin{array}{l}\text { Composite } \\
\text { Reliability }\end{array}$ & $\begin{array}{c}\text { Average } \\
\text { Variance } \\
\text { Extracted } \\
\text { (AVE) }\end{array}$ & $\begin{array}{c}\text { R- } \\
\text { square }\end{array}$ \\
\hline Economic & 0.777 & 0.794 & 0.858 & 0.603 & \\
\hline Environment & 0.679 & 0.708 & 0.860 & 0.754 & \\
\hline $\begin{array}{l}\text { Excellent } \\
\text { Public } \\
\text { Transportation }\end{array}$ & 0.877 & 0.884 & 0.902 & 0.510 & 0.518 \\
\hline Social & 0.772 & 0.801 & 0.867 & 0.684 & \\
\hline
\end{tabular}

\subsection{Discriminant Validity}

Discriminant validity measured how far the differences of a construct with other constructs. High value of discriminant validity can be determined as a special or unique variable and described the measured phenomenon.

According to Table 9 and Table 10, we compare the latent variable covariance with the square root of AVE. It is depicted that all of square root of AVE value are higher than latent variable covariances. So, discriminant validity criteria are fulfilled for all variables.

Table 9: Latent Variable Covariances

\begin{tabular}{|l|l|l|l|l|}
\hline Variable & Economic & Environment & $\begin{array}{l}\text { Excellent } \\
\text { Public } \\
\text { Transportation }\end{array}$ & Social \\
\hline Economic & $\mathbf{1 . 0 0 0}$ & 0.569 & 0.640 & 0.535 \\
\hline Environment & 0.569 & $\mathbf{1 . 0 0 0}$ & 0.511 & 0.606 \\
\hline $\begin{array}{l}\text { Excellent } \\
\text { Public } \\
\text { Transportation }\end{array}$ & 0.640 & 0.511 & $\mathbf{1 . 0 0 0}$ & 0.618 \\
\hline Social & 0.535 & 0.606 & 0.618 & $\mathbf{1 . 0 0 0}$ \\
\hline
\end{tabular}

Table 10: Square Root of AVE

\begin{tabular}{|l|l|l|l|}
\hline \multicolumn{1}{|c|}{ Variable } & \multicolumn{1}{|c|}{ AVE } & \multicolumn{1}{|c|}{ (AVE) } & Discriminant Validity \\
\hline Economic & 0.603 & 0.776531 & Fulfilled \\
\hline Environment & 0.754 & 0.868332 & Fulfilled \\
\hline $\begin{array}{l}\text { Excellent Public } \\
\text { Transportation }\end{array}$ & 0.51 & 0.714143 & Fulfilled \\
\hline Social & 0.684 & 0.827043 & Fulfilled \\
\hline
\end{tabular}

\subsection{Composite Reliability}

Reliability test is done by calculating composite reliability. The minimum value of the composite reliability is 0.6 . according to Table 8, all of the construct indicator has higher value than 0.6 , so it can be defined that the model has high reliability and reliable. Furthermore, Cronbach's Alpha is set an additional parameter. The minimum of Cronbach's Alpha values in the variable to be reliable is 0.7. According to Table 8, all of Cronbach's Alpha values are higher than 0.7 , except the environment variable (0.679). So, the www.astesj.com reliability of three variables (economic, social, and excellent public transportation) is high, but the environment variable has low reliability.

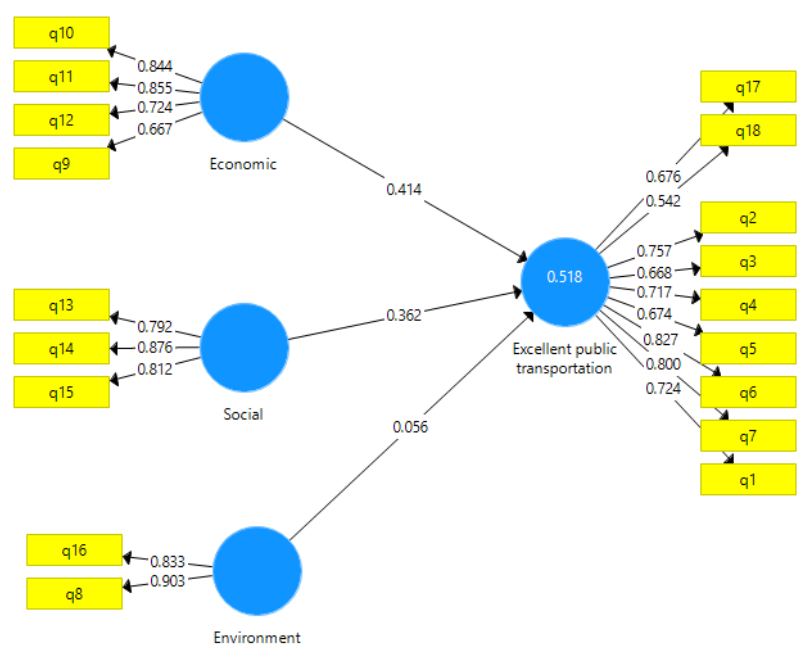

Figure 3: Final Structured Model

\subsection{Structural Model Analysis}

The subsequent analysis is a structural model. The analysis is conducted to measure the correlation among the constructs or variables, significance, R-squared. According to Figure 3, it is depicted that the number between the yellow rectangle and the blue circle (on the arrow) is cross loading factors value or outer loading value of the model. The description of the value can be referred to Table 7. Furthermore, the values between the blue circle of economic, social, and environment variable and the blue circle of excellent public transportation (on the arrow) is the Original Sample (O) value. Those values can be seen in Table 11. The number on the blue circle of excellent public transportation is Rsquared value. The value is 0.518 , it means that the expectation of contribution toward BRT execution is at moderate level. The rest is affected by other factors from the outside that are not described in this study.

Table 11: Coefficient Path Structured Model

\begin{tabular}{|l|c|c|l|l|l|}
\hline Variable & $\begin{array}{c}\text { Original } \\
\text { Sample } \\
(\mathrm{O})\end{array}$ & $\begin{array}{c}\text { Sample } \\
\text { Mean } \\
(\mathrm{M})\end{array}$ & $\begin{array}{c}\text { Standard } \\
\text { Deviation } \\
(\text { STDEV })\end{array}$ & $\begin{array}{c}\text { T Statistics } \\
(|\mathrm{O} / \mathrm{STDEV}|)\end{array}$ & $\begin{array}{c}\text { P- } \\
\text { Values }\end{array}$ \\
\hline $\begin{array}{l}\text { Economic -> } \\
\text { Excellent } \\
\text { Public } \\
\text { Transportation }\end{array}$ & 0.414 & 0.422 & 0.072 & 5.745 & 0.000 \\
\hline $\begin{array}{l}\text { Environment } \\
\text {-> Excellent } \\
\begin{array}{l}\text { Public } \\
\text { Transportation }\end{array}\end{array}$ & 0.056 & 0.056 & 0.102 & 0.549 & 0.583 \\
\hline $\begin{array}{l}\text { Social -> } \\
\text { Excellent } \\
\text { Public } \\
\text { Transportation }\end{array}$ & 0.362 & 0.364 & 0.078 & 4.672 & 0.000 \\
\hline
\end{tabular}

The differences of Figure 2 (initial model) and Figure 3 (final model) is at removing the Q19 indicator. The removed Q19 is caused by the loading factor in convergent validity measurement is less than 0.5 . The effect is the final model is more valid than the 


\section{F. Romadlon / Advances in Science, Technology and Engineering Systems Journal Vol. 5, No. 4, 795-804 (2020)}

initial model, but the R-squared of the initial model (0.524) is a little bit higher than the final model $(0.518)$. Furthermore, the Original Sample $(\mathrm{O})$ value of the initial model is not entirely different from Original Sample $(\mathrm{O})$ value of the final model.

After finishing the model structural analysis, it is processed the bootstrapping. The result can be seen in Table 11. According to the table, economic variables have t-statistics at 5.745 , or greater than 1.96 (alfa is $5 \%$ ) or p-value is less than $0.05(0.000)$. It means that the economic variable has a significant factor with excellent public transportation variable. Furthermore, the social variable has tstatistics at 4.672, and the p-value is 0.000 . It means that the social variable has a significant factor toward excellent public transportation variable. Meanwhile, the environment variable has t-statistics less than $1.96(0.549)$ and p-value is at 0.583 (greater than 0.05 ). It means that environment variable has no significant factor for excellent public transportation variable. So, only the economic and the social variables which have a significant factor for excellent public transportation variable.

Regarding the Original Sample (O) value, the correlation among those variables shows that the economic and the social variables has a significant correlation with excellent public transportation variables. The value is 0.414 and 0.362 . However, for environment variable does not have a significant correlation with excellent public transportation variables and the value is 0.056 . So, the economic variable affects the excellent public transportation variable is at $41.4 \%$, and the social variable is at $36.2 \%$. Nevertheless, the environment variable does not affect to excellent public transportation variables.

\subsection{Implication and Recommendation}

The BRT is new and has been followed the service procedure to fulfil ridership service. The objective of the BRT is to connect ridership and local community or non-ridership. Ridership means people who use the BRT frequently. Non-ridership means the people whether they use the BRT or not, but they get the impact of the BRT execution. In this case, they are defined as marginal community. The role of them is important to support the BRT sustainability and enhance the public engagement.

The demographics result depicts that most non-ridership is non-formal occupations such as street food sellers and pedicab drivers. Furthermore, most of them are never tried the BRT. It is indicated that the BRT implementation or execution belongs to ridership in terms of the service. Indeed, the BRT is set for ridership, but non-ridership shall get the impact at least increasing the opportunity to access, and gain the new transportation mode, economic opportunity, and positive social impact.

According to the survey result of the correlation between demographics with presumptions, living areas of the non-ridership are more frequent, giving significant factors, followed age ratio and gender. The different living areas of non-ridership leads to different presumptions about the BRT schedule, economic productivity, economic opportunity, local mobility, reducing traffic accidents, and low fossil fuel use. Most of the non-ridership in Purbalingga is labour. They rely on public transportation that supported their mobility. So, they need less waiting time at the BRT stop. The BRT provider shall adjust the condition by adding more frequent bus schedules in Purbalingga at peak hours [35].

Economic productivity and opportunity factors depict that Purbalingga has lower economic status than Purwokerto. The economic status is the ability of the non-ridership to access the industry or economic centre [30]. Actually, Purbalingga has more factories, but Purwokerto is more developed than Purbalingga, such as ease of public transportation access and strategic geographical area. So, the BRT shall open new opportunities for non-ridership to open their economic access and develop Purbalingga to be similar economic status with Purwokerto. It can be done by promoting the tourism object, traditional food, museum, and some interesting places, so that increase nonridership economic opportunities.

Reducing traffic accidents and using fossil fuel less, the BRT can be a pioneer of public transportation that excellent for safety driving and green transportation. It will lead the use of excellent vehicles standard to support both cities to be more eco-friendly mobility and increase local or non-readership healthy.

Meanwhile, the age ratio factor influences different presumption among the non-ridership in terms of traffic congestion and e-payment. In term of traffic congestion, a different age ratio has different background. So, some of non-ridership who use private vehicle trust that the BRT can reduce traffic congestion, especially at peak hours. Furthermore, some non-ridership agree that the BRT shall provide an e-payment system. Actually, the payment system will ease the provider to record the ridership occupancy. So, it can be reliable transport and reach all society segmentation in terms of preparing a new model of the payment system.

The last is the gender that has significant presumption in term of accommodating their destination. Recently, the BRT facilities shall be improved, mainly to attract women. The non-ridership women hope that the BRT can accommodate their destination with appropriate and comfort facilities [36]. So, it will reduce nonridership women using a private vehicle [37].

Referring to the structured model from SEM-PLS, it is indicated that economic and social variable have significant factors to excellent public transportation variable. It means that the nonridership is strongly agree that the social and economic variables must be applied with BRT execution. The social and economic variables are perceived by non-ridership, whether direct or indirect effect such as enhance social mobility, reduce traffic accidents and congestion, and opening economic opportunity and access. According to the phenomenon, the BRT provider shall capture the opportunity by enhancing the service onboard and offboard. Onboard service is for ridership and off-board service is nonridership. Onboard service is universal and the procedure is standardized but off-board service can be set as a sustainable society development program. Environment variable does not have a significant correlation with the excellent public transportation variables. It is indicated that the availability of the BRT is far from the green transportation campaign. Indeed, the primary purpose of the BRT is minimizing traffic congestion and promoting sustainable transportation with low $\mathrm{CO} 2$ emissions [38]. However, by implementing green public transportation, the BRT provider shall invest more and sometimes it will not be required recently, especially in developing countries.

According to the structural model from SEM-PLS for excellent public transportation variables, the expectation of contribution toward the BRT execution is $51.8 \%$. It is moderate level and still far from the expectation. However, it needs more empirical study to improve the percentage, so that the phenomenon can be captured wider. 


\section{F. Romadlon / Advances in Science, Technology and Engineering Systems Journal Vol. 5, No. 4, 795-804 (2020)}

The non-ridership as marginal community is taken to offer significant improvement service by the BRT provider. The BRT provider can improve the journey time, journey time reliability, and realistic alternative mass transportation [29]. By knowing the presumption of the non-ridership, the BRT provider can purpose some program to enhance the BRT occupancy and improve the service. Meanwhile, the social, economic, and environment benefits can be gained to attract more public engagement among the programs. The program can be designed as facilitating economic opportunity program, social development program, and promoting green transportation program.

\section{Conclusions}

BRT in Purwokerto and Purbalingga is new public transportation that is operated by the Ministry of Transport. As the new public transportation, the support from the non-ridership is a compulsory to maintain the sustainability. According to the analysis, it gives the insightful results;

1) The living area has dominance influenced factors, followed age ratio and gender about the BRT condition. The living area covers the presumption about the BRT schedule, economic opportunity and productivity, local mobility access, reducing traffic accident, and fossil fuel use. For the age ratio, it covers traffic congestion and e-payment system, and the gender covers the destination presumption.

2) The SEM-PLS model shows that social and economic criteria have correlation with excellent public transportation criteria, but not with environment criteria. So, it can be a suggestion to the BRT provider to concern more environmental issue to raise the community awareness and the public engagement.

In the BRT provider side, the suggestion will lead to purpose some programs to improve the service and increase the occupancy. In the non-ridership side, the proposed program will attract the sense of awareness and the public engagement from the BRT execution. Furthermore, the model is demonstrated at the moderate percentage, so the future research in this area can be directed to add more variables to reach excellent public transportation. The added variables such as specific involved communities, political will, regulation, gender equality, economic opportunity, and local culture to capture more public engagement.

\section{Conflict of Interest}

The author declares no conflict of interest.

\section{Acknowledgment}

This acknowledgement is given to Ministry of Education and Culture Republic of Indonesia for the funding. We thank so much to the BRT ridership who gave free time to fill our questionnaire and also surveyor team from Industrial Engineering and Information System Department, IT Telkom Purwokerto, Central Java, Indonesia.

\section{References}

[1] O. Afolabi, "Commuters Perception and Preferences on The Bus Rapid Transit in Lagos State," JORIND, 14(2), 2016.

[2] J. Cao, X. Cao, C. Zhang, X. Huang, "The gaps in satisfaction with transit services among BRT, metro, and bus riders: Evidence from Guangzhou," Journal of Transport and Land Use, 97-109, 2015, doi:10.5198/jtlu.2015.592.

[3] D. Darwis, Fatmawati, Nasrulhaq, "Hubungan Kualitas Pelayanan dengan Kepuasan Masyarakat Pengguna Bus Rapid Transit (BRT) Maminasata," Administrasi Publik, 3, 2017.

[4] J.M. Bunker, "High volume bus stop upstream average waiting time for working capacity and quality of service," Public Transport, 10(2), 311-333, 2018, doi:10.1007/s12469-018-0179-1.

[5] M. Islam, M. Brussel, A. Grigolon, T. Munshi, "Ridership and the BuiltForm Indicators: A Study from Ahmedabad Janmarg Bus Rapid Transit System (BRTS)," Urban Science, 2(4), 95, 2018, doi:10.3390/urbansci2040095.

[6] D. Oviedo, L. Scholl, M. Innao, L. Pedraza, "Do Bus Rapid Transit Systems improve accessibility to job opportunities for the poor? The case of Lima, Peru," Sustainability (Switzerland), 11(10), 2019, doi:10.3390/su11102795.

[7] D.A. Rodriguez, C.E. Vergel-Tovar, "Urban development around bus rapid transit stops in seven cities in Latin-America," Journal of Urbanism, 11(2), 175-201, 2018, doi:10.1080/17549175.2017.1372507.

[8] E. Saputra, C. Widyasmara, "The effect of urban spatial structure on rapid bus transit services in Yogyakarta and Surakarta, Indonesia: A comparative study of the Trans Jogja and the Batik Solo Trans," Geografia - Malaysian Journal of Society and Space, 10(2), 46-58, 2014.

[9] S. Tao, J. Corcoran, I. Mateo-Babiano, D. Rohde, "Exploring Bus Rapid Transit passenger travel behaviour using big data," Applied Geography, 53, 90-104, 2014, doi:10.1016/j.apgeog.2014.06.008.

[10] L. Prayogi, "The Influence of Bus Rapid Transit System on Urban Development: An Inquiry to Boston and Seoul BRT Systems," International Journal of Built Environment and Scientic Research, 1(1), 18, 2017.

[11] A. Koling, W.-B. Zhang, K. Zhou, H. Meng, Bus Rapid Transit ( BRT ) Toolbox : Assessing Person Throughput to Measure Transportation Impacts for BRT Projects, 2018.

[12] S. Tabassum, S. Tanaka, F. Nakamura, "Improving Access considering Commuters 'Perception ( A Case Study of Lahore BRT ) Keywords :," International Journal of Innovative Research in Engineering and Management (IJIREM), 3(4), 283-289, 2016.

[13] M. Woldeamanuel, C. Olwert, "The Multimodal Connectivity at Bus Rapid Transit (BRT) Stations and the Impact on Ridership," Journal of the Transportation Research Forum, 55(1), 87-102, 2016, doi:10.5399/osu/jtrf.55.1.4340.

[14] B. Ferhan, X. Zhou, "Drivers , Barriers and Implementation of Social Sustainable in Supply Chain A qualitative study of SMEs," 1-83, 2016.

[15] S. Nasrin, "Acceptability of Bus Rapid Transit ( BRT ) to Commuters in Dhaka," 2015.

[16] H.I. Okagbue, M.O. Adamu, S.A. Iyase, E.A. Owoloko, On the Motivations and Challanges Faced by Commuters Using Bus Rapid Transit in Lagos, Nigeria, The Social Sciences, 10(6), 696-701, 2015, doi:10.3923/sscience.2015.696.701.

[17] J. Dubé, F. Des Rosiers, M. Thériault, P. Dib, "Economic impact of a supply change in mass transit in urban areas: A Canadian example," Transportation Research Part A: Policy and Practice, 45(1), 46-62, 2011, doi:10.1016/j.tra.2010.09.002.

[18] J.B. Ingvardson, O.A. Nielsen, "Effects of new bus and rail rapid transit systems-an international review," Transport Reviews, 38(1), 96-116, 2018, doi:10.1080/01441647.2017.1301594.

[19] E. Adewumi, D. Allopi, "An Appropriate Bus Rapid Transit System," International Journal of Science and Technology Volume 3 No. 4, 3(4), 248-254, 2014.

[20] A.P. Ajayi, "Assessment of the Influence of Lagos Bus Rapid Transit Scheme (BRT-Lite) on Road Traffic Crashes (RTC) on Lagos MainlandIsland Corridor," The Open Transportation Journal, 11(1), 102-109, 2017, doi: $10.2174 / 1874447801711010102$.

[21] A. Nikitas, M. Karlsson, "A Worldwide State-of-the-Art Analysis for Bus Rapid Transit: Looking for the Success Formula," Journal of Public Transportation, 18(1), 1-33, 2015, doi:10.5038/2375-0901.18.1.3.

[22] A. Mishra, S.A.S.A. Kumar, P. Pradeep, "Study of Bus Rapid Transit system In Respect to Growing Cities of India," Nternational Journal of Engineering Research \& Technology (IJERT), 2(10), 1378-1383, 2013.

[23] M. Poku-Boansi, G. Marsden, "Bus rapid transit systems as a governance reform project," Journal of Transport Geography, 70(June), 193-202, 2018, doi:10.1016/j.jtrangeo.2018.06.005.

[24] S.R. Majumdar, "The case of public involvement in transportation planning using social media," Case Studies on Transport Policy, 5(1), 121-133, 2017, doi:10.1016/j.cstp.2016.11.002.

[25] E. Cascetta, F. Pagliara, "Public Engagement for Planning and Designing Transportation Systems," Procedia - Social and Behavioral Sciences, 87, 
103-116, 2013, doi:10.1016/j.sbspro.2013.10.597.

[26] K. Rangarajan, S. Long, A. Tobias, M. Keister, "The role of stakeholder engagement in the development of sustainable rail infrastructure systems," Research in Transportation Business and Management, 7, 106-113, 2013, doi:10.1016/j.rtbm.2013.03.007.

[27] N. Hassen, P. Kaufman, "Examining the role of urban street design in enhancing community engagement: A literature review," Health and Place, 41, 119-132, 2016, doi:10.1016/j.healthplace.2016.08.005.

[28] J.R. Gardner, R. Rachlin, H.W.A. Sweeney, A. Sweeny, H.W. Allen, Handbook of Strategic Planning, Wiley, 1986.

[29] D. Mobereola, Lagos Bus Rapid Transit Africa' s first BRT scheme (The Lagos BRT-Lite System), 2009.

[30] U. Dutta, "A Framework to Identify Economic and Community Benefits of the Proposed BRT System in Southeast Michigan," Current Urban Studies, 05(02), 164-184, 2017, doi:10.4236/cus.2017.52010.

[31] N. Duduta, C. Adriazola, D. Hidalgo, L.A. Lindau, R. Jaffe, "Understanding road safety impact of high-performance bus rapid transit and busway design features," Transportation Research Record, 2317, 8-14, 2012, doi:10.3141/2317-02.

[32] V.J. Racehorse, G. Zhang, A. Sussman, A. Jian, T. Parker, "Bus rapid transit system deployment for high quality and cost-effective transit service: A comprehensive review and comparative analysis," IET Intelligent Transport Systems, 9(2), 175-183, 2015, doi:10.1049/iet-its.2013.0176.

[33] D. Prabowo, BRT Purwokerto Terus Tambah Halte, Radar Banyumas, 2019.

[34] A. Rifai, "Partial Least Square-Structural Equation Modeling (PLS-SEM) untuk mengukur ekspektasi penggunaan repositori lembaga: Pilot studi di UIN Syarif Hidayatullah Jakarta," Al-Maktabah, 14(1), 56-65, 2015.

[35] P. Starkey, J. Hine, Poverty and Sustainable Transport How Transport Affects Poor People with Policy Implications for Poverty Reduction: A literature review, 2014.

[36] D. Martinez, E. Salgado, P. Yañez-pagans, Connecting to Economic Opportunity? The Role of Public Transport in Promoting Women' $s$ Employment in Lima, 2018.

[37] K. Terayama, M. Odani, "Expected role of public transportation services in securing residents' accessibility to the city center in suburban housing development areas," Transportation Research Procedia, 25, 4258-4269, 2017, doi:10.1016/j.trpro.2017.05.237.

[38] L. Velazquez, N.E. Munguia, M. Will, A.G. Zavala, S.P. Verdugo, "Sustainable transportation strategies for decoupling road vehicle transport and carbon dioxide emissions," 26(3), 373-388, 2015, doi:10.1108/MEQ07-2014-0120. 